\title{
BUCO-DENTAL ORIENTATION AND INSPECTION AT PRIMARY SCHOOLS OF THE STATE OF SÃO PAULO (1911-1917)
}

Angélica Pall Oriani*

\section{ABSTRACT}

The purpose of this article is to analyze prescriptions for oral dental inspections officially adopted in primary schools in São Paulo. It investigates official publications that help to read the guidelines given for the inspection, handling and care of children's teeth and mouths within the school space are investigated. It explores the relationship established between teething, school progress, and civilization, as well as the conduct adopted in cases of poor dental condition. Conclusions highlight the good results of problematizing the meanings attributed to the practices of inspection and physical examinations and the approximations made between the school and the scientific discourses elaborated about it.

Keywords: hygiene, buco-dental inspection, history of Education.

\footnotetext{
* Centro Universitário Sagrado Coração (UNISAGRADO), Bauru/SP, Brasil.
} 


\section{ORIENTAÇÃO E INSPEÇÃO BUCO-DENTÁRIA NAS ESCOLAS PRIMÁRIAS DO ESTADO DE SÃO PAULO (1911-1917)}

\section{RESUMO}

O propósito deste artigo é analisar as prescrições para inspeção buco-dentária adotadas oficialmente nas escolas primárias paulistas. Investigam-se publicações oficiais que auxiliam a ler as orientações dadas para a inspeção, manejo e cuidado com dentes e bocas das crianças dentro do espaço escolar. São exploradas a relação estabelecida entre a dentição, o adiantamento escolar e a civilização, assim como a conduta adotada nos casos de mau estado dentário. Como conclusões são destacadas a fecundidade de problematizar os sentidos atribuídos às práticas de inspeção e de exames físicos e as aproximações feitas entre a escola e os discursos científicos elaborados a respeito dela.

Palavras-chave: higiene, inspeção Buco-dentária, história da Educação.

\section{ORIENTACIÓN E INSPECCIÓN BUCODENTAL EN ESCUELAS PRIMARIAS DEL ESTADO DE SAO PAULO (1911-1917)}

\section{RESUMEN}

El propósito de este artículo es eanalizar las prescripciones para la inspección bucodental adoptadas oficialmente en las escuelas primarias de Sao Paulo. Se investigan publicaciones oficiales que ayuden a leer las pautas dadas para la inspección, manipulación y cuidado de los dientes y la boca de los niños dentro del espacio escolar. Se explora la relación entre la dentición, el avance escolar y la civilización, así como la conducta adoptada en casos de mal estado dental. Las conclusiones presentan la fecundidad de problematizar los sentidos atribuidos a las prácticas de inspección y los exámenes físicos y las aproximaciones realizadas entre la escuela y los discursos científicos elaborados al respecto.

Palabras clave: higiene, inspección bucodental, historia de la Educación.

\section{ORIENTATION ET INSPECTION BUCCO-DENTAIRE DANS LES ÉCOLES PRIMAIRES DE LÉTAT DE SÃO PAULO (1911-1917)}

\section{RESUMÉ}

Le but de cet article est d'analyser les prescriptions pour l'inspection bucco-dentaire adoptées officiellement dans les écoles primaires paulistes. On recherche les publications officielles qui aident à lire les directives données pour l'inspection, la manipulation et les soins des dents et de la bouche des enfants dans l'espace scolaire. On étudie la relation établie entre la dentition, la réussite scolaire et la civilisation, ainsi que la conduite adoptée en cas de mauvais état dentaire. Les conclusions mettent en évidence l'importance de problématiser les sens attribués aux 
pratiques d'inspection et d'examens physiques et les rapprochements faits entre l'école et les discours scientifiques élaborés à son propos.

Mots-clés : hygiène, inspection Bucco-dentaire, histoire de l’Éducation. 


\section{INTRODUCTION}

The reflections contained in this article stem from postdoctoral research, which thematized the circulation of knowledge about hygiene to primary schools in the state of São Paulo during the first decades of the 2oth century ${ }^{1}$. Despite the general focus of the research, the incursion in the documentation and specialized bibliography on the subject has made it feasible to identify the importance attributed to the detailed practices of inspection of children's bodies in primary schools.

Many of the defenses about the importance of developing physical examinations in schoolchildren were based on eugenic assumptions that articulated the sanitation of the nation to the school (CARVALHO, 1998; ROCHA, 2003a; 2003b; 2015): it was about cleansing society by school ${ }^{2}$. Thus, in the first decades of the 2oth century, the inspection of children's bodies became an increasingly defended conduct under the auspices of the medical discourse. Examining height, weight, auditory and visual acuity, mental and cognitive development, and dentition allowed physicians who worked in the school context to identify and classify schoolchildren within categories of "normality" or "abnormality" (ROCHA, 2003b).

Specific reflections that raise approximations between medical, educational, and dental discourses, such as those proposed in this article, are fruitful since they promote an interesting movement of widening borders and a consequent expansion of the field of Education History. They're still simple and sparse, though. For instance, I have found only the texts of Oliveira (2012) and Oliveira; Matos (2018) specifically thematizing such issues. This reflective

\footnotetext{
${ }^{1}$ The research was carried out at UNESP - Universidade Estadual Paulista, Marília Campus, under the supervision of the Ph.D. Ana Clara Bortoleto Nery and it ended in July 2020.

2 Saneamento pela educação is the title of the doctoral thesis defended by Antonio Ferreira de Almeida Júnior, in 1922, at USP Medical School (Faculdade de Medicina e de Cirurgia de São Paulo). Within the scope of the Institute of Hygiene, acting as an assistant in the School Hygiene section, Almeida Júnior contributed to the dissemination and proposition of health policies in the state of São Paulo (ROCHA, 2003b); (BERTUCCI, 2013); (ORIANI, 2021, in press).
} 
proposal assumes relevance as it aims to contribute to filling these gaps.

Regarding the sources used for the analysis, it is worth highlighting the importance of the Annuarios do Ensino do Estado de São Paulo3 for the problematization of a set of authorized discourses that sought to conform to and show a certain reality. Such documents fulfilled the purpose of propagating the achievements of the São Paulo educational system, as well as conducting a certain reading of what was developed and achieved as a model in the field of education. Under the auspices of "showing" a certain reality, Annuarios do Ensino help not only to understand but also to question this logic of "visibility" (CARVALHO, 2011) and the education administrators' concerns regarding health-educational policies adopted in that period.

Regarding the guidelines on hygiene, such documents provided a school medical inspection from individual examinations that aimed at children to consider aspects such as vision, hearing, dentition, and mental faculties. Rocha (2015) states that in the proposals of the meticulous inspection that was systematically guided by Balthazar Vieira de Mello - the physician who chaired the service of School Medical Inspection - the sense assumed by the official interventions adopted in São Paulo was materialized to remove the schoolchildren from racial degeneration.

Regarding the chronological delimitation, it is worth justifying that the year 1911 corresponds to the creation of the School Medical Inspection Service (Inspeção Médica Escolar, IME) linked to the São Paulo State Sanitary Service. The establishment of this agency is celebrated in this year's Annuario do Ensino, which presents information on the implementation of school medical inspection and dental care in schools, with emphasis on the anthropometric examinations and the need to create offices for the performance of physical and dental examinations in schools.

In 1916, the IME was transferred to the General Directory of Public

3 To facilitate naming, these documents will be referred to as Annuarios do Ensino. 
Instruction, which led to the publication of detailed guidelines on medicalschool inspection written by the head of the service, Balthazar Vieira de Mello, and published in the 1917 Annuarios do Ensino. In addition, prescriptions like those embodied in the official document are also found in the book authored by the inspector, entitled "Higiene escolar e pedagogia: para uso de medicos, educadores e estabelecimentos de ensino".4, also published in 1917. This book includes guidelines on the individual examination procedures of children and the hygiene inspection of the school space, the classroom, and learning in broad terms.

Taken as part of the dissemination of hygienic principles, the guidelines in the official documents and in the book mentioned, which point to the examination of schoolchildren's bodies and particularly schoolchildren's dentition, are part of the set of actions that linked health and civilization. Mobilizing readings that interpret the "social" mouth (KOVALESKI; FREITAS; BOTAZZO, 2006) as a construct through which subjectivities are produced and reflecting on the treatment given to the administration of good teeth 5 and the management of bad teeth, this study aims to discuss the meanings attributed to medical-dental inspections in the school environment, as well as the approximations operated between the different types of knowledge and the school space.

\section{MANAGING THE SCHOOLCHILDREN' HEALTH}

As previously mentioned, the EMI was created in 1911, depending on the São Paulo State Sanitary Service, due to the reform of the State Sanitary Code (ROCHA, 2003a). According to the Decree n. 2.141, of November 14, 1911,

\footnotetext{
4 Considering this is historical research, the spelling is as presented in the original document.

5 Based on the documents, the administration of good teeth is a practice of care and zeal related to dentition, including the constant vigilance and the use of dentifrices aiming to keep the teeth healthy.
} 
the duties of this agency referred to guidelines on the construction of school buildings according to hygienic measures; choice of school furniture, teaching methods and processes, school positions and attitudes, distribution of the subjects, class hours, breaks, and physical exercises; prophylaxis of transmissible diseases; individual examination of teachers, schoolchildren, and employees; and vaccination of the school staff (SÃO PAULO, 1911, art. 67).

Rocha (2015) states that placing the school as a privileged space for intervention was an agenda internationally defended by the hygienist movement at medical and pedagogical congresses held during the second half of the 19th century and the first decades of the 2oth century. In line with these demands, the creation of the EMI incorporates protocols aimed at caring for and inspecting the schoolchildren's health and recording information to identify the children's physical type and produce anthropometric data.

It is worth highlighting the movement around the responsibility for the work of the EMI. According to Rocha (2015), the EMI, initially subordinated to the São Paulo State Sanitary Service, was remodeled in 1916 and transferred to the General Directory of Public Instruction. Balthazar Vieira de Mello was the head of the service since its creation in 1911. It is possible to notice that the articulation between the medical inspection service and the public instruction was fundamental for the intensification regarding the "[...] physical examination of the schoolchildren and the recording of their data, which should compose their health record." (ROCHA, 2015, p. 377). The performance of Vieira de Mello was essential.

In addition, the school medical inspection service was bureaucratical, which included the administrative and medical remodeling of the institute and the administrative and medical service organization in the capital and the interior of the state. As a result, Balthazar Vieira de Mello also defined guidelines on the work to be carried out by the medical inspectors, including updated individual records with school classification schemes.

With the discrimination of the service, there were guidelines on the 
monitoring and hygienic inspection of school spaces. These guidelines were derived carefully from inspection protocols, which included health records that help to illustrate the lenses the medical inspectors should look at the schools.

Thus, the records filled the purpose of directing the evaluation. Their models can be found in the "Relatório dos serviços realizados durante o anno de $1917 "$ in the Annuario do ensino that was published in the same year in which Balthazar Vieira de Mello presents his main guidelines on school medical inspection.

Image 1 - Model n. 1 of the assessment record.

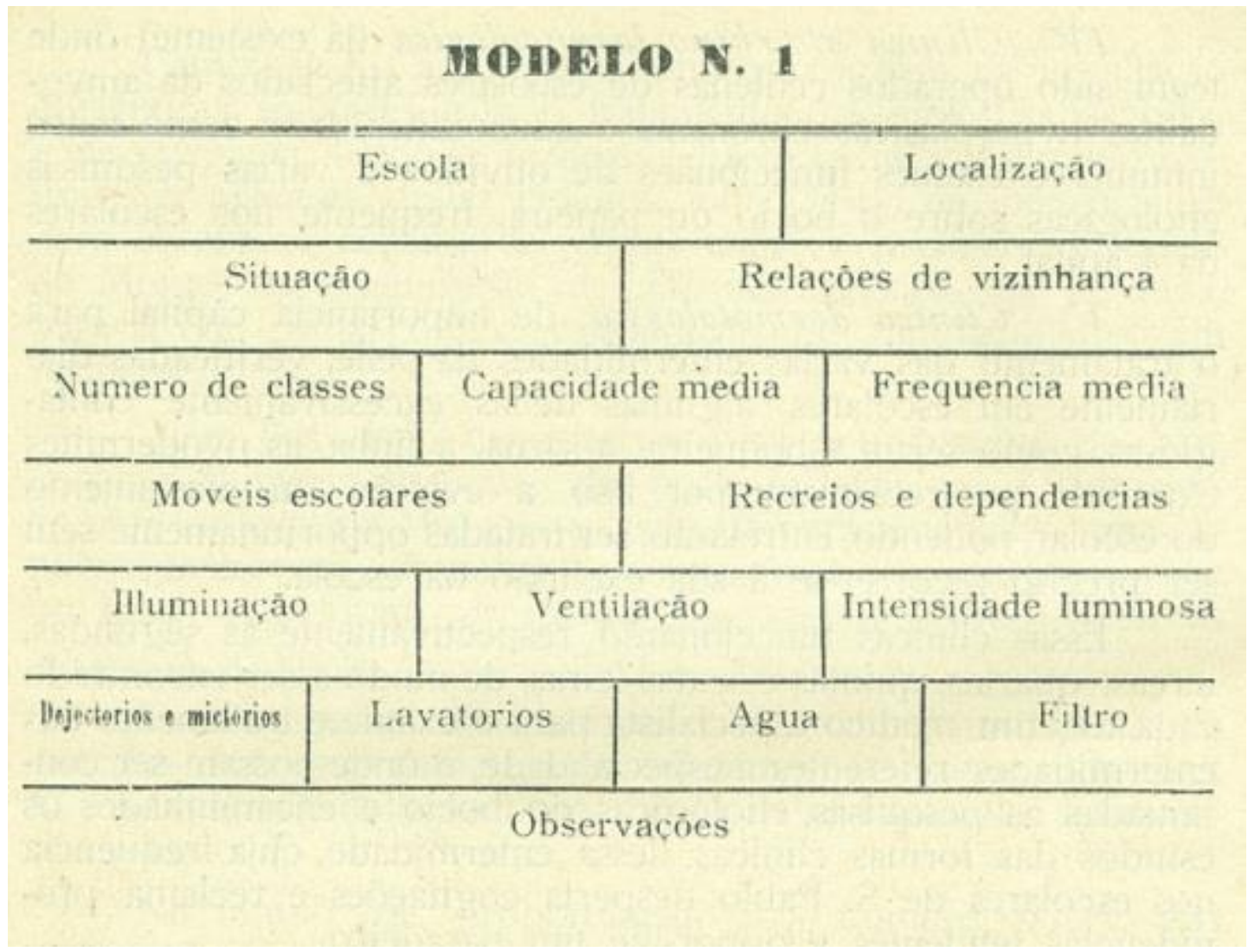

Source: São Paulo (1917, p. 398). School; Location; Situation; Neighborhood; Number of classes; Average capacity; Average attendance; School furniture; Breaks and facilities; Lighting;

Ventilation; Light intensity; Toilet; Urinal; Washbasin; Water; Filter; Observations. 
As it is possible to notice, location, child-friendly furniture, brightness, ventilation, and layout are essential elements to be inspected within the perspective adopted by Vieira de Mello. In this regard, it is worth noticing that a book published in 1902, as stated by Rocha (2005), entitled " $A$ hygiene na escola", already defended the importance of looking at the school as a place of health and disease-free. Written during a period in which Vieira de Mello acted as a sanitary inspector at the São Paulo State Sanitary Service, this author had already accumulated experience defending medical intervention in various social spaces.

According to Rocha (2005, p. 95), in the book 1902, Balthazar Vieira de Mello already considers the school as a teaching place and advocates a location for the school in the city, "[...] proposes ways of organizing the school space and, at the same time, seeks to institute an educational dimension for this space.". Vieira de Mell also considered other aspects of its location; on this issue, Rocha (2005, p. 95) explores

[...] the numerous interdictions stated aim to create a distance from factories, workshops, churches, train stations, headquarters, prisons, hospitals, cemeteries, and stables. Distant of the noise and exhalations, of the world of work, sickness, and death, the school is considered a place of silence, attention, and, above all, a place of health.

Such questions are defended and endorsed in "Higiene escolar $e$ pedagogia", published in 1917, a different moment for Balthazar Vieira de Mello. He had already been the head of the EMI since 1911, as mentioned above, but his work was subordinated to the General Directory of Public Instruction from 1916. With this book, authorized by the Government of the State of São Paulo, he organized a guide to direct the work of medical school inspectors (ROCHA, 2005).

Despite the fifteen-year time gap between publications, Balthazar Vieira 
de Mello's hygienic defenses regarding the need to provide attention to soil, neighborhoods, geographical orientation, the number of flooring, and other issues remained.

In addition to inspecting schools, the centrality of anthropometric examinations gained importance for Vieira de Mello. Rocha (2015) analyzes that the detailed census of children's bodies followed the logic of classification and production of "ideal types". The school medical service, as presented in a report of the EMI services, in the Annuario do Ensino, would give attention not only to the examination but, mainly, to the recording of the schoolchildren's characteristics. Individual records promote an anthropometric and classificatory repertoire of the schoolchildren (SÃO PAULO, 1917).

Therefore, height, weight, respiratory capacity; levels of attention, memory, and intelligence; and aspects of the eyes, teeth, face, and hair were measures and features that met the purpose of disclosing information that would be useful to the knowledge of the hygiene conditions of schoolchildren and schools. Regarding these measures and their uses, there is a close relationship between the anthropometric and pedagogical classifications that justify the adoption of hygienic practices and conduct at the regeneration and good school progress. 
Image 2 - Individual record model n. 2.

\begin{tabular}{|c|c|c|c|c|c|c|}
\hline \multicolumn{7}{|c|}{ MODELO N. 2 } \\
\hline NORMAL & Proporcional & & ormal & Supernorma & & ANORMAL. \\
\hline Escola & \multicolumn{5}{|c|}{ Nome } & Idade \\
\hline Tez & \multicolumn{2}{|c|}{ Physionomia } & \multicolumn{2}{|c|}{ Tesenrolrimento physico } & & Nutriçáo \\
\hline \multicolumn{7}{|c|}{ Exame geral } \\
\hline Estatura & \multicolumn{2}{|c|}{ Peso } & \multicolumn{2}{|c|}{ Capacidade rexpiratoria } & \multicolumn{2}{|c|}{ Força muscular } \\
\hline \multicolumn{7}{|c|}{ Observaçōes } \\
\hline
\end{tabular}

Source: SÃO PAULO (1917, p. 398). Normal; Proportional; Subnormal; Supernormal, Abnormal; School; Name; Age; Skin; Complexion; Physiognomy; Physical development; Nutrition; General examination.

In "Higiene escolar e pedagogia" (1917), Balthazar Vieira de Mello carefully guides the medical conduct in physical examinations developed in schoolchildren. The description of protocols of such examinations includes the inspection of the skin appendage, nose, nostrils, nervous system, mouth, dentition, visual acuity, respiratory capacity, among others. There are also photographs during the examinations, as shown in the following image, which allows us to notice the character of guiding that Balthazar Vieira de Mello wanted to print to his book. 
Image 3 - Example of physical examination to measure pulmonary capacity.

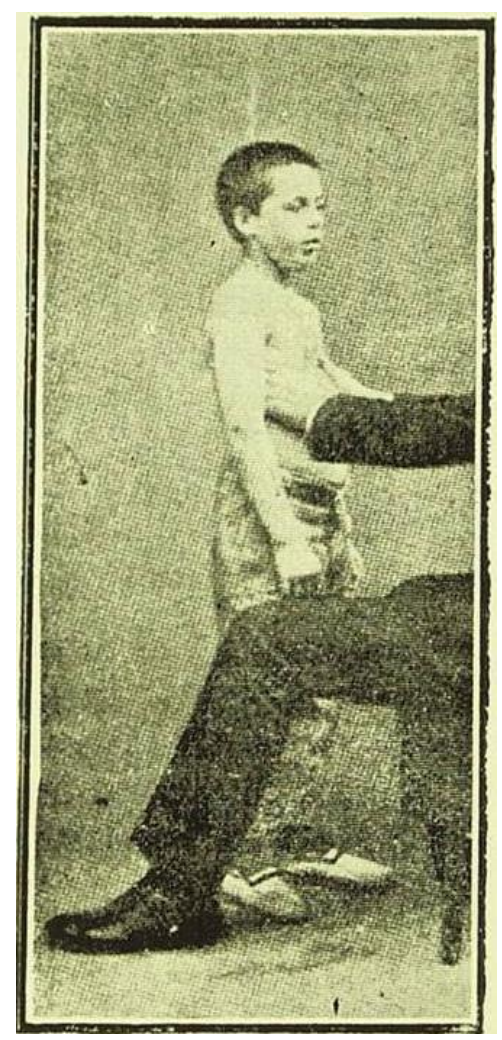

Source: Mello (1917, p. 93).

The orientation for individual records is also highlighted in Vieira de Mello's book, especially considering the importance of the evaluation and pedagogical classification of schoolchildren within the categories of "normal" and "abnormal".

Thus, it is possible to notice a significant commitment of Balthazar Vieira de Mello in the organization of projects designed to include the debates initiated by the medical corporation and the hygienist movement to intervene in the school space. The defenses and guidelines on the medical inspection of schoolchildren and school space show how the school has become organized based on medical rationality (ROCHA, 2003a; 2003b, 2015).

In addition, the transfer of the EMI to the General Directory of Public Instruction can be an action that allowed greater visibility of the work developed 
within this agency. As an example, it is possible to mention the inclusion of reports of the activities in the Annuarios do Ensino, the reorganization of the service offered, and, as a result, the form by which the medical doctrinehygienist gained legitimacy and space as it internalized the school space in an official way.

The contents published in the Annuarios do Ensino and in Balthazar Vieira de Mello's book, as previously explored, allow us to question the mobilization of medical knowledge as a tool of administration and hygiene control of schoolchildren' bodies. The physical examination added to other strategies, such as the dissemination of pedagogical knowledge from textbooks and school routines, which included the supervision and the defense of hygiene habits, worked as devices used in the school space aiming at the execution of a political and sanitary project.

In this space of dissemination of exemplary practices and conduct to be followed, both the Annuarios do Ensino and the book of Balthazar Vieira de Mello fulfill the purpose of administering spaces and bodies. By showing the actions developed within the EMI and directing those that should be done, Vieira de Mello helped produce a set of practices considered appropriate and necessary for the functioning of the sanitizer project from the school (ROCHA, 2003b; 2015). In this prestigious place, where medical knowledge is mobilized and enters the school space, and appear dental care; to treat or eliminate bad teeth can be considered strategies quite representative for understanding how "civilization" should be incorporated in the lives of schoolchildren: assessing which habits would continue and which would be eliminated (OLIVEIRA, 2012; OLIVEIRA; MATOS, 2018). 


\section{THE BUCO-DENTAL INSPECTION IN PRIMARY SCHOOLS IN SÃO PAULO}

According to the content of the Annuarios do Ensino and Balthazar Vieira de Mello's book, the buco-dental inspection should consider the condition of the gums, the dentition, and the presence of cavities. Also, there was a plan to investigate "adenoid vegetations and hypertrophical chronicle amygdalates" (SÃO PAULO, 1917; MELLO, 1917). Care with the schoolchildren's mouth would be added to the anthropometric examination and the investigation of hearing, eyes, sensations, and breathing organs.

The school doctor should examine an Anthropometric Office, but often there were not such spaces and neither doctors to reach all regions and schools. Thus, the appeal to philanthropy and to the support of the medical class for the performance of such examinations in needy cities as attested by the reports contained in the Annuarios do Ensino highlight the attempts of Balthazar da Vieira Mello to carry out his hygiene work for students and school.

The example of the "Dental Assistance Dispensaries" is illustrative. The State Government approved its installation in September 1912, and the São Paulo Association of School Dental Assistance supported it. Created under the auspices of the São Paulo Association of Dental Surgeons, these Dispensaries depended at first on private support or on philanthropic entities to have equipment ${ }^{6}$.

However, from 1913, the São Paulo City Council approved, through the Law no. 1758 of December, 6 of that year, financial aid of 5,00o contos de réis to School Dental Assistance. Thus, it was possible to open more Dispensaries in the city of São Paulo. In 1929, when the Decree 4.600 of May 30 regulated the

\footnotetext{
${ }^{6}$ In the capital of São Paulo, there was the Dispensário da Luz, which operated in the Prudente de Moraes School Group with the support of Ms. Escholastica Melchert da Fonseca. The Dispensário da Barra Funda, supported by Baroness Heduwiges Duprat, was in a homonymous school group. The Dispensário da Bela Vista operated in a school group that had the same name and was built with the support of Ms. Leonor Tibiriçá Sampaio Coelho (SÃO PAULO, 1911, p. 48).
} 
"School Dental Service" for the first time, there were 25 Dental Assistance Dispensaries (NARVAI; FRAZÃO, 2008).

The Dispensaries inaugurated in the capital of São Paulo promoted a dental-pedagogical intervention in the school scenario, which aimed to make a healthy race emerge from the school since it was "necessary for reaching an ideal Homeland" (OLIVEIRA; MATOS, 2018, p. 1264). In "Higiene escolar $e$ pedagogia" (1917), Balthazar de Vieira Mello praises the achievements of the Dispensaries opened in 1912 and presents two new ones: one dispensary created in the Belenzinho School Group and another in the Cambuci School Group.

One aspect that draws attention is the number of Dispensaries in the state capital and their absence in the interior. The geographical divisions between the capital and the interior allow us to visualize not only spatial limits but also imaginary, political, and symbolic ones. Thus, the presentation of the number of Dispensaries in the capital and the procedures carried out in that area is accompanied by silence regarding the interior or the indication that they "[...] are far from what they should be, in fact. " (SÃO PAULO, 1917, p. 392).

The inspection and dissemination work of medical and dental services in the interior depended almost exclusively on philanthropic works. There are reports on charitable actions, given the official limits, as observed below.

In the interior, [...] school dental clinics have already been established in Lorena, Parahybuna, Amparo, and Brodowski. There was another in the process of implementation in the Edifício da Escola Normal de Pirassununga, and prospectively, more would be set in school groups in Araraquara, Jundiahy, Tieté, and Itú. A medical dispensary may also be in Itú.

Campinas and Casa Grande also consider establishing school clinics for the treatment of mouth and throat disorders. Professor Jorge Leme managed to hold a charity party in Campinas. Professor Deodato de Mores is committed to doing the same in Casa Grande, counting on the cooperation of volunteers who lived there. (SÃO PAULO, 1917, p. 395-396). 
Another important aspect is the orientation regarding the functioning of the Dispensaries, also presented in the Annuarios do Ensino; they should take advantage of the deployed organization of the school groups to serve children in the period opposite to the school shift.7 Thus, the boys, who attended the school in the morning, would be assisted in the Dispensaries in the afternoon; and the girls, who attended the school in the afternoon, would be assisted in the Dispensaries in the morning. The school doctor should provide them with a medical referral, including their data so that they could be assisted.

There should also be a record for the inspection of oral health. In this regard, the one presented in the 1911 Annuario do Ensino illustrates the practice of archiving and producing health records for schoolchildren. Its image is an example.

Image 4 - Individual oral health record.

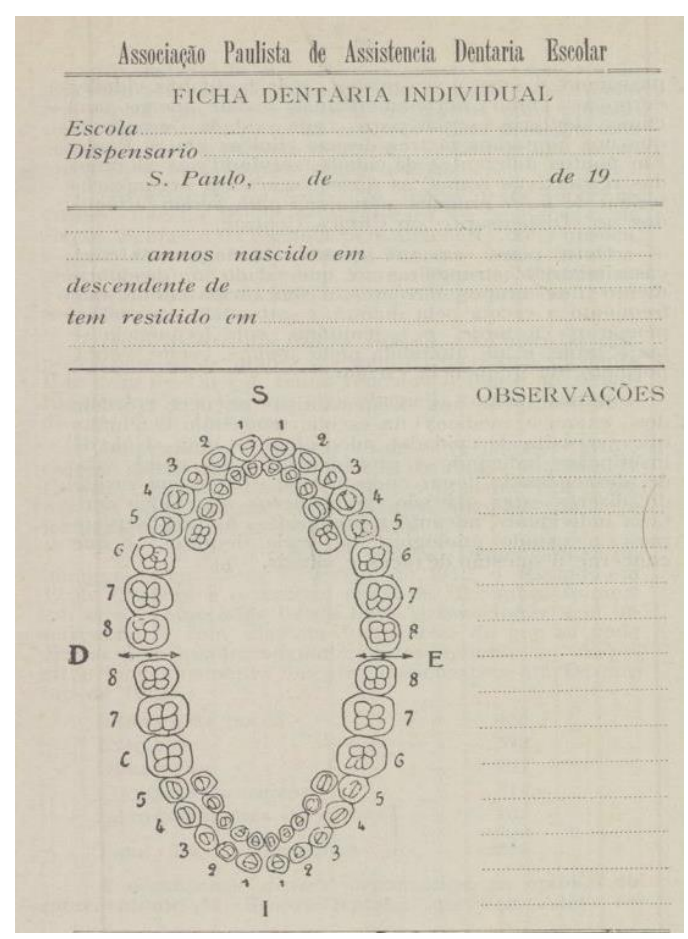

7 The practice of deploying the shifts of school groups began in 1908. The deployment started in 1928 to meet the growing demand for schools, especially in large urban centers. 
Fonte: São Paulo (1911, p. 50). School; Dispensary; Date; Age; City of birth; Descendent, and Address.

The practice of recording this information occurs with zeal: an " $\mathrm{X}$ " is marked on the extracted tooth, the black dot on the tooth with caries, and information annotated includes number, plan, and right or left side.

Through the records, Balthazar Vieira de Mello aimed to produce data that would serve for the "etiological evaluation of dental caries regarding climate and race" (SÃO PAULO, 1911, p. 49). Furthermore, one of the arguments endorsing the need for registration is its importance in the case of cadaverous identification, "[...] it is sufficient to resort to the individual dental record of the suspect of an accident, suicide or crime." (SÃO PAULO, 1911, p. 51).

Schwarcz (1993) states that hygiene in Brazil appears to be associated with poverty and the black and mestizo population. Thus, using data to identify crimes is related to the idea that producing data is a way of promoting eugenics. Rocha (2015) also states the mapping of the physical and mental development of children, who attended schools in different areas of the State of São Paulo, seems to suggest Balthazar Vieira de Mello's alignment with the conceptions that attributed "[...] to miscegenation, the possibility of whitening, by the absorption of the so-called 'lower races'; whitening that did not only concern physical traits, but also social behavior "(p. 383 emphasis added). In this sense, school hygiene would relate to this task of eugenizing Brazilian children.

The oral-dental inspection is also in the book "Higiene escolar $e$ pedagogia" (1917). Balthazar Vieira de Mello suggests the examination begins with the lips, followed by the palate, the tongue, the gums, and, subsequently, teething. The school doctor would only be interested in the second dentition, which would begin about the ages five or six and would continue throughout the school years. 
Image 5 - Appearance scheme of the teeth.

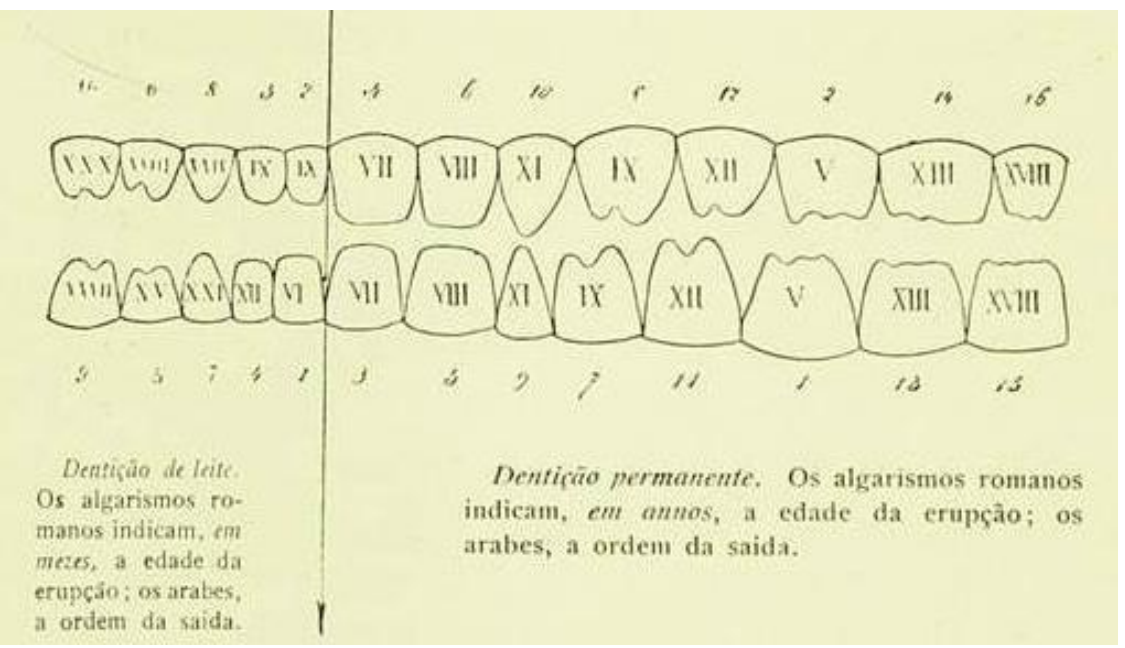

Fonte: Mello (1917, p. 87) Deciduous teeth; The Roman numerals indicate, in months, the age and the sequence of eruption. Permanent teeth; The Roman numerals indicate, in years, the eruption age and sequence.

Addressing the examination of the mouth and dentition in Higiene escolar e pedagogia (1917), Balthazar de Vieira Mello guides the school doctor regarding what is called a dental anomaly, such as Hutchinson's ${ }^{8}$ teeth that is a characteristic of congenital syphilis (MELLO, 1917). There is also a reflection on the jaw. According to Vieira Mello, the conformation of the jaws accompanies the vicious accommodation of the teeth that can project forward and to the side. In addition, the author describes the conformation may present a decrease in the diameter in its upper part, thus molding itself in a " $\mathrm{V}$ " shape; the detection of this anomaly could assist in the diagnosis of congenital or acquired idiocy or the detection of "supernormal" children (MELLO, 1917, p. 92).

The concern about dental malformation, especially regarding caries, is present both in the book and in the Annuarios do Ensino, which link the appearance of caries to infectious diseases, as it is possible to observe in the excerpts below:

${ }^{8}$ The English physician Jonathan Hutchinson (1829-1913) was the first to describe dental formation associated with congenital syphilis. 


\begin{abstract}
Among the numerous septic complications of dental caries, we highlight the inflammation and suppuration of the submaxillary ganglia, dental abscesses, osteitis, which are sometimes followed by partial maxillary necrosis in more than anything, the tuberculous infection, caused by the inflammation of the maxillary ganglia and favored by dental caries, which serves as a gateway to the tuberculosis bacillus. (MELLO, 1917, p. 89).
\end{abstract}

[...] dental caries in the children causing the child's general wasting, due to malnutrition, imperfect chewing, and infection of the gastrointestinal tube, prepares their body to host the germ of tuberculosis, which originates, according to Ferrier ${ }^{9}$, to a large extent, directly or indirectly in tooth decay. (SÃO PAULO, 1911, p. 51).

To avoid caries and other complications, the Dental Assistance Dispensaries had numbers that showed their intense performance. For instance, the Annuario do Ensino from 1911, which also covers 1912, presents a list of procedures carried out in the scope of the three Dispensaries located in the capital between September and December 1912, which add to 2251. There are 456 mouth examinations, 573 extractions, 727 fillings, 314 surgical dressings, and 181 cleanings. Comparing data, in 1912, the number of schoolchildren enrolled in the school groups that had Dispensaries was 2678 in total, subdivided into 1099, in the Prudente de Moraes School Group; 769, at the Barra Funda School Group; and 810, in the Bela Vista School Group (SÃO PAULO, 1911, p. 118).

Regarding the number of procedures, some considerations are necessary so that it is possible to look at the numbers with caution and problematize them. Numbers need to be considered approximately since documents do not inform how many children had the procedures or whether there was overlap or hierarchy between them. For instance, a child had a mouth examination, an extraction of more than one tooth, and procedures of cleaning or filling.

9There was no information on Ferrier and Dr. Ross, mentioned by Balthazar Vieira de Mello. 
Thus, some questions arise: was there extraction, filling, or cleaning without examining the mouth?; the mouth examination was conducted again by the dentists at the Dispensaries even after the children had already been inspected and referred by the school doctors, i.e., was there an articulation between the medical and dental services in these schools ?; and, in schools where there were no Dispensaries, after the oral inspection carried out by the inspector, what was the referral after filling the data on the individual records when caries were caries detected: referral to Dispensaries or other entities ?; finally, the inaccuracy of the terms referred to in the documents is something to be mentioned: "mouth examination" and "oral inspection", as guided by Balthazar Vieira de Mello, refer to the same behaviors? ${ }^{10}$.

There are several ways to reflect on the presence of doctors and dentists in the school space. Despite the analytical precautions that the lack of documentation requires and the caution in analyzing the data, the number of procedures listed in the Annuarios do Ensino continues to be surprising considering such a short period. Even in an approximate way, these numbers allow us to visualize the importance that the care given to oral hygiene had assumed throughout this historic moment. Also, these pieces of information allow the exploration of the conduct adopted in cases of poor dental conditions.

The elimination of unhealthy teeth seems to represent the possibility of restoring and embodying civilization into the school, also guaranteeing the chance of improvement as learners (OLIVEIRA, 2012; OLIVEIRA; MATOS, 2018). This is very noticeable in these documents as they present direct relations between "dental hygiene and civilization"11 (SÃO PAULO, 1917) or between good teeth condition and school progress: "In this, Dr. Ross' studies,

\footnotetext{
${ }^{10}$ Due to the absence of documents that would allow the exploration and indication of these answers, they were registered to present the various paths not yet followed by the reflection proposed in this article.

${ }^{11}$ It is important to record the documents establish a direct relationship between good dental status and civilization. This link allows us to explore that, in the hygienist project endorsed and conducted by Balthazar Vieira de Mello, there would be a counterpoint between disease and health that would materialize in what is called "civilization". A healthy nation, under this perspective, would be a sane nation.
} 
which were carried out in Switzerland and established the rule that the degree of advancement of the schoolchildren is directly related to the good or bad condition of their teeth are well known." (SÃO PAULO, 1911, p. 51).

As highlighted by Mott; et al. (2008, p. 105):

\begin{abstract}
The concern with children's health was also in the mouth, considered a gateway for several diseases, such as tuberculosis. The belief in the direct relationship between teeth condition and physical and mental health - even between teething, delinquency, and school performance motivated dentists and educators to start campaigns, implement services, write educational children's stories and education books for mothers, and share the need for the use of toothbrushes and toothpaste.
\end{abstract}

Furthermore, the reflections of Botazzo (2008), identifying caries as a "fetish" of dentistry, help to direct the reading of this growing care with the mouth in its bodily materiality. Based on the assumption that the mouth would be the part of the body that mediates the subject's relationship with the world and the humanization process itself, dental caries were a civilization disease. Collectively taking care of oral health raises concern about the mouth and its diseases in this interaction of social and subjective aspects.

Since the mouth is the place of desire, passion, and support through which it becomes possible to interact with others, Botazzo (2008) distinguishes "dentistry" and "oral health". The second does not exempt good teeth, and it requires an approach that contemplates other functions of the mouth and the subject to which the mouth belongs.

Such demarcations are essential to debate the relationship the areas of medicine and dentistry have developed with teeth. They embody health and, when disposable, become an autonomous object, which must be extinguished at the slightest sign that it can compromise learning and allow the onset of other diseases.

By looking at the mouth, as proposed by Kovaleski, Freitas, and Botazzo 
(2006), and observing it under the register of the production of subjectivities and the disciplinarization of individuals, it becomes possible identify the production of knowledge of medicine and dentistry as instruments for this discipline. This is possible either through its inspection practices, examinations, and procedures or through recommendations and campaigns that spread the importance of the purchase of toothbrushes and the use of toothpaste.

Supported by the medical and dental areas that entered the school space, oral-dental inspection practices aimed to control and monitor mouths to discipline children. As a result, Kovaleski, Freitas, and Botazzo (2006, p. 102) affirm: "We have reached the peak of inversion: the mouth that consumes the world must now be consumed by an area of knowledge (or market), materialized in the dentist's prophylactic practices."

These reflections and those of Oliveira (2012) and Oliveira and Matos (2018) allow us to verify that the establishment of Dental Assistance Dispensaries in public schools and oral inspection practices, as conducted by medical inspectors and guided by Balthazar Vieira de Mello, resulted in the development of "[...] a pedagogy of the mouth, mobilizing politicians and educators in favor of building a population that is hygienic and correct regarding the orthodontology." (OLIVEIRA; MATOS, 2018, p. 1267) ${ }^{12}$.

\section{FINAL CONSIDERATIONS}

From the documentation explored in this study, it has been possible to verify the fruitfulness of problematizing the places and meanings attributed to

\footnotetext{
${ }^{12}$ Although it is not the scope of this study, an aspect noticed due to analytical fertility refers to the fact that the concern with children's oral health and the consequent creation of services aimed at this purpose opened a new job market, especially for female dentists, in the scenario of the first decades of the twentieth century: private clinics, assistance entities, and schools. According to Mott; et al. (2008), the consolidation of the presence of women in dentistry was articulated to the transformations in concepts such as health and disease, to the institutionalization of professions, and changes in health policies. One of them is the possibility of working in schools and in entities assisting children's oral health.
} 
hygienic practices and medical, ophthalmological, auditory, oral, mental, and pedagogical practices, as well as the approximations made between the school and the broad set of scientific discourses elaborated about it.

The Annuarios do Ensino e Higiene escolar e pedagogia (1917), by Balthazar Vieira de Mello, help to illustrate how school health management has become essential conduct within a project that aims to remodel habits of the population and nation (CARVALHO, 1998; ROCHA, 2003a). Thus, the careful inspection of the school spaces, the body, the intellect, and the teeth worked to incorporate or restore civility in schoolchildren.

The number of procedures performed with the support of Dental Assistance Dispensaries and the financial, political, and administrative investment in the care of the teeth of children enrolled in school groups brings to light how the schoolchildren's mouths were considered as to their good functioning.

In this regard, it is worth exploring the conquest of the school space by doctors and dentists in conjunction with the hygienic and educational demands that aimed to domesticate the schoolchildren' bodies and produce cleaner, healthier, and more sane citizens.

The bibliography that addresses these themes, such as Rocha (2003; 2015), Gondra (2004a; 2004b), and others, has allowed the verification of the fertility of this detailed look for the concretization of the defenses around the hygiene of habits and nation from the school. Using the reflection and taking as a reference the studies by Oliveira (2012), Oliveira and Matos (2018), Kovaleski, Freitas and Botazzo (2006), and Botazzo (2008), it is possible to verify how the discourse enunciations concretized in dental education campaigns, inspections, and modifications in the institutionalized dental knowledge began to configure a new space for doctors and dentists to act: the schoolchildren's mouth. Therefore, care with poor teeth quality and the prevention of diseases, such as tuberculosis and syphilis, are related not only to child hygiene but also to good school performance. 


\section{REFERENCES}

BERTUCCI, Liane. Sanear a raça pela educação. Teses da Faculdade de Medicina e Cirurgia de São Paulo, início dos anos 1920. In: MOTA, André; MARINHO, Maria Gabriela Silva Martins da Cunha (Org.). Eugenia e história: ciência, educação e regionalidades. São Paulo: USP, Faculdade de Medicina: UFABC: CDG Casa de Soluções e Editora, 2013. p. 219-238.

BOTAZZO, Carlos. A cárie dentária como fetiche. Primeiras notas. In: BOTAZZO, Carlos; OLIVEIRA, Maria Aparecida de. Atenção básica no Sistema Único de Saúde: abordagem interdisciplinar para os serviços de saúde bucal. São Paulo: Artes e Letras Editora e Gráfica, 2008. p. 219-238.

CARVALHO, Marta Maria Chagas de. Pedagogia Moderna, Pedagogia da Escola Nova e Modelo Escolar Paulista. In: CARVALHO, Marta Maria Chagas de; PINTASSILGO, Joaquim. Modelos Culturais, saberes pedagógicos, instituições educacionais. São Paulo: Editora da Universidade de São Paulo/FAPESP, 2011. p. 185-212.

CARVALHO, Marta Maria Chagas de. Molde nacional e fôrma física: higiene, moral e trabalho no projeto da Associação Brasileira de Educação. Bragança Paulista: EDUSF, 1998.

GONDRA, José Gonçalves. Artes de Civilizar: medicina, higiene, educação escolar na Corte. Rio de Janeiro: EDUERJ, 2004a.

GONDRA, José Gonçalves. Combater a "Poética Pallidez": a questão da higienização dos corpos. Perspectiva, Florianópolis, v. 22, n. especial, p. 121161, jul./dez. 2004b.

KOVALESKI, Douglas Francisco; FREITAS, Sérgio Fernando Torres; BOTAZZO, Carlos. Disciplinarização da boca, a autonomia do indivíduo na sociedade do trabalho. Ciência \& Saúde Coletiva, Rio de Janeiro, v. 11, n. 1, p. 97-103, 2006.

MELLO, Balthazar Vieira. A hygiene na escola. São Paulo: Tipografia do Diário Oficial. 1902.

MELLO, Balthazar Vieira. Higiene escolar e pedagogia: para uso de medicos, educadores e estabelecimentos de ensino. São Paulo: Casa Vanorden. 1917.

MOTT, Maria Lucia et al. 'Moças e senhoras dentistas': formação, titulação e mercado de trabalho nas primeiras décadas da República. História, Ciências, 
Saúde - Manguinhos, Rio de Janeiro, v.15, Supl., p.97-116, jun. 2008.

OLIVEIRA, Iranilson. Práticas educativas e sensibilidades médico-pedagógicas: a educação da saúde bucal e das expressões faciais (Parahyba, 1919-1945). In: SEMINÁRIO NACIONAL DE ESTUDOS..., Anais, 9, Universidade Federal da Paraíba, p. 2494-2511, jul-ago. 2012.

OLIVEIRA, Iranilson; MATOS, Maria Izilda. "Para a maior glória do nosso Brasil": a educação e cuidados para a saúde bucal infantil, 1912-1940. História, Ciências, Saúde - Manguinhos, Rio de Janeiro, c. 25, n. 4, out.-dez. 2018, p. 1261-1279.

ORIANI, Angélica Pall. Higiene para as escolas primárias: a produção escrita de Antonio Ferreira de Almeida Júnior (1922-1939). Educação e Pesquisa, 2021 (No prelo).

ROCHA, Heloísa Helena Pimenta. A higienização dos costumes. Educação escolar e saúde no projeto do Instituto de Hygiene de São Paulo (1918-1925). Campinas, SP: Mercado das Letras: Fapesp, 2003a.

ROCHA, Heloísa Helena Pimenta. Entre o exame do corpo infantil e a conformação da norma racial: aspectos da atuação da Inspeção Médica Escolar em São Paulo. História ciência e Saúde - Manguinhos. Rio de Janeiro, v. 22, n. 2, abr./jun. 2015.

ROCHA, Heloísa Helena Pimenta. Educação escolar e higienização da infância. Cadernos CEDES, São Paulo, 2003b, v. 23, n. 59, p.39-56.

ROCHA, Heloísa Helena Pimenta. Inspecionando a escola e velando pela saúde das crianças. Educar, Curitiba, n. 25, p. 91-109, 2005. Editora UFPR.

SÃO PAUlO. Annuario do ensino do Estado de São Paulo. Livros Didacticos. São Paulo: Typographia do "Diário official”, 1917.

SÃO PAUlO. Annuario do ensino do Estado de São Paulo. Livros Didacticos. São Paulo: Typographia do “Diário official”, 1911-1912.

SÃO PAULO. Decreto n. 2.141, de 14 de novembro de 1911. Reorganiza o serviço sanitário do estado, 1911.

SÃO PAULO. Lei n. 1758, de 6 de dezembro de 1913. Autoriza o Prefeito a conceder o auxilio de 5:000\$ooo á Associação Paulista Dentária Escolar, 1913.

NARVAI; P. C; FRAZÃO, P. Políticas de saúde bucal no Brasil. In: MOYSÉS, Samuel Jorge; KRIEGER, Léo; MOYSÉS, Simone Tetu. Saúde bucal das 
famílias: trabalhando com evidências. São Paulo: Editora Artes Médicas, 2008, p. 1-20.

SCHWARCZ, Lilian Moritz. O espetáculo das raças: cientistas, instituições e questão racial no Brasil do século XIX. São Paulo: Companhia das Letras, 1993.

ANGÉLICA PALL ORIANI é doutora em Educação pela Unesp-Marília. Professora dos cursos de licenciatura do Centro Universitário Sagrado Coração, em Bauru-SP, onde também coordena a graduação em Pedagogia. Desenvolve pesquisas na área de história da escola, com ênfase para as instituições marginais e para as relações entre educação e saúde.

E-mail: angelicaoriani@hotmail.com

(1) http://orcid.org/0000-0003-3647-6820

Recebido em: 08 de outubro de 2020

Aprovado em: 04 de janeiro de 2021

Editora responsável: Terciane Luchese

Revista História da Educação - RHE

Associação Sul-Rio-Grandense de Pesquisadores em História da Educação - Asphe Artigo de acesso aberto distribuído nos termos de licença Creative Commons. 